\title{
California's Citizen Redistricting Commission, Electoral Competitiveness and Political Polarization
}

\author{
James M. De Vault \\ Department of Economics, Lafayette College, Easton, USA \\ Email: devaultj@lafayette.edu
}

How to cite this paper: De Vault, J. M. (2016). California's Citizen Redistricting Commission, Electoral Competitiveness and Political Polarization. Open Journal of Po-

litical Science, 6, 413-432.

http://dx.doi.org/10.4236/ojps.2016.64036

Received: September 13, 2016

Accepted: October 14, 2016

Published: October 17, 2016

Copyright $\odot 2016$ by author and Scientific Research Publishing Inc. This work is licensed under the Creative Commons Attribution International License (CC BY 4.0).

http://creativecommons.org/licenses/by/4.0/

\begin{abstract}
Passage of Proposition 20 in California in 2010 transferred the power to redistrict congressional seats from the state legislature to a new independent redistricting commission. The goals of this transfer were to increase electoral accountability, to reduce partisan bias, to promote greater transparency and to bolster public trust. In this paper, I analyze the impact of Proposition 20 on electoral accountability by examining its effect on electoral competitiveness and political polarization. The evidence in the paper demonstrates that Proposition 20 has enhanced competitiveness and reduced polarization but that these effects are modest to date.
\end{abstract}

\section{Keywords}

California, Redistricting Commission, Competition, Polarization

\section{Introduction}

In recent years, the decennial process of congressional redistricting has increasingly come under scrutiny as electoral competition has declined and political polarization has intensified. The following excerpt from a recent USA Today editorial summarizes these concerns:

Congress is overrun with hyperpartisans because the game is tilted. Legislatures in too many states have spent decades gerrymandering districts that strongly favor one party or the other. That means most incumbents fear the other party less than a challenge from a competitor in their own party.

The result: Deep red and deep blue House districts produce highly partisan politicians who rarely have to cater to independents or members of the other party to 
get elected, and have no incentive to do that once they get to Washington ${ }^{1}$.

The public perception that legislative redistricting is warping electoral outcomes and weakening the political process has fueled a reform movement designed to depoliticize redistricting. This reform movement has culminated in the establishment of independent redistricting commissions in Arizona, California, Idaho and Washington. These commissions are charged with drawing district lines for House seats, for seats in state legislatures, or both. The purpose of commissions varies, but most agree that the primary goals are to increase political accountability, to reduce partisan bias, to increase transparency, and to restore public confidence in the electoral process.

Ironically, the academic literature on redistricting finds only weak evidence that redistricting is the primary driver of either declining electoral competitiveness or increasing political polarization. Other factors, such as geographic sorting (Chen \& Rodden, 2013), the growing importance of campaign finance (Abramowitz, Alexander, \& Gunning, 2006), rising income inequality (McCarty, Poole, \& Rosenthal 2006) and an increasingly divided American electorate (Mann, 2006) are generally viewed as dominating the effect of redistricting. Nonetheless, several studies (Carson et al., 2007; Grainger, 2010; Theriault, 2008) find evidence that redistricting may be a significant factor.

Even assuming legislative redistricting does undermine electoral competition and heighten polarization, it is not clear that independent redistricting commissions will necessarily correct or reduce these problems. For example, Miller and Grofman (2013) find "only very limited evidence" that commission-based redistricting produces better outcomes than legislative redistricting. Similarly, Masket, Winburn and Wright (2012) find little evidence that commission-based redistricting enhances competition or reduces polarization. In contrast, McDonald (2006) argues that until very recently, many commissions were neither independent nor non-partisan, so it is too early to tell whether truly independent, non-partisan commissions are capable of producing better redistricting outcomes than state legislatures. Winburn (2011) argues that when independent commissions are combined with "process-based regulations", they may indeed reduce the worst effects of gerrymandering. Finally, Carson, Crespin and Williamson (2014) find some limited evidence that redistricting commissions do enhance competition.

The goal of this paper is to reconsider the effects of redistricting commissions by focusing on the impact of the California Redistricting Commission (CRC). The CRC went into effect with the 2010 redistricting cycle and is of interest because, as Cain (2012) points out, it is about as close to a truly independent and non-partisan commission as we are likely to get. While a number of authors have previously analyzed the impact of the CRC (Kogan \& Kouser, 2011; Kogan \& McGhee, 2013; Masket, 2013; Kousser, Phillips, \& Shor, 2014), much of this analysis has focused on issues other than competitiveness and polarization. This paper examines these two issues in greater detail

${ }^{1}$ http://www.usatoday.com/story/opinion/2013/11/19/tea-party-redistricting-gerrymandering-primaries-elect ions-editorials-debates/3645711/ 
than previous work and uses more recent data as well. To address issues related to competitiveness, it examines changes in victory margins, incumbency reelection rates, challenger quality, and voter registration patterns. To assess the impact of redistricting reform on political polarization, it examines changes in DW-Nominate scores and relates these changes to changes in voter registration patterns. The results indicate that redistricting reform has increased competitiveness and reduced polarization but that these effects are modest to date.

I limit my attention to California's congressional delegation and do not consider the impact on California's state Senate or Assembly because my primary concern is with competitiveness and polarization in the US Congress. There is no reason to believe that the CRC plan will affect these three groups differently and previous empirical shows that there are only slight differences, at least in terms of the impact on competitiveness (Kogan \& McGhee 2013). Given that California has more than 50 congressional districts, the sample is large enough to produce robust statistical inference even in the absence of data on the state legislature.

The paper begins by providing a brief review of the recent history of redistricting in California, including a summary of the electoral reforms recently adopted by California. It then examines the theoretical relationship between redistricting, competitiveness and political polarization. The impact of redistricting on electoral competitiveness and polarization is then considered using a variety of empirical measures and techniques. The paper concludes with a brief discussion of the implications of the empirical results.

\section{Redistricting Reform in California}

In the four redistricting cycles preceding the 2010 cycle, redistricting in California was marked by controversy in each case ${ }^{2}$. In two of these cycles (1970 and 1990), the legislature and the governor were unable to reach agreement on a redistricting plan, so the California Supreme Court appointed three Special Masters and charged them with the task of developing redistricting plans for Congress, the State Assembly and the State Senate, which they did. In the 1980 cycle, even though agreement was reached between a Democratically-controlled legislature and a Democratic governor, the resulting redistricting plans were rejected in three statewide referendum. New redistricting maps were ultimately implemented as a result of a ruling by the California Supreme Court, but these maps did not differ greatly from the original maps.

The 2000 redistricting cycle produced the most controversial plan of all. In this cycle, redistricting was under Democratic control because Democrats had majorities in both legislatures and also controlled the governorship. Despite this, Democrats worked with Republicans to produce a plan that unambiguously sought to protect incumbents. As a result, 50 of the 51 incumbent members of California's congressional delegation who stood for reelection in 2002 won their seats ${ }^{3}$. Critics of the plan argued that it created districts that were too safe, leading to heightened polarization as incumbents maneu${ }^{2}$ Passantino (2008) and Cain (2012) provide a more complete description of the history of redistricting and reapportionment in California.

${ }^{3}$ Only Congressman Gary Condit was defeated, and that was almost certainly due to a scandal involving him. 
vered to head off more radical challengers in primary elections. Evidence for this contention is found in the fact that only a single seat changed party control in the five elections held under this plan.

While a number of redistricting reforms had been considered and rejected prior to the 2000 redistricting cycle, the impetus for reform was strengthened by the blatant nature of the 2000 redistricting plan (Kogan \& McGhee, 2012). The reform movement ultimately culminated in the passage of Proposition 11 in 2008 and Proposition 20 in 2010. Proposition 11 created the Citizens Redistricting Commission (CRC) for the purpose of redistricting State Assembly and State Senate seats. Proposition 20 extended the scope of the CRC to include the redistricting of seats in Congress. The CRC produced its first redistricting plans in 2011 and modified versions of these plans went into effect with the 2012 election.

The CRC is designed to depoliticize the redistricting process and to insure that congressional and legislative districts are drawn in a manner that is consistent with neutral redistricting criteria. The fourteen members of the CRC are carefully screened to insure that they have not run or been appointed to political office in the last ten years, have not been employed by a candidate for political office in the last ten years, have not served as a registered lobbyist in the last ten years and have not contributed more than two thousand dollars to any political candidate in the last ten years. CRC members are explicitly instructed to consider the following criteria (in order of importance) when developing redistricting plans: equal population, Voting Rights Act compliance, geographic contiguity, communities of interest, compactness and political subdivisions. To insure transparency, the $\mathrm{CRC}$ is required to hold its meetings in public and to solicit written comments as well as redistricting maps from the public. Finally, a supermajority of nine members is required for the passage of any plan.

It is important to note that the redistricting criteria that guide the CRC do not specifically mention either electoral competitiveness or political extremism. While many advocates of redistricting reform argued that reform would enhance competition and reduce polarization, the fact that $\mathrm{CRC}$ was not instructed to consider either of these objectives when developing redistricting plans means that meeting either objective is by no means certain.

Before going any further, it is important to point out that California implemented another major electoral reform in the 2012 elections which significantly complicates the analysis (Amoros et al., 2016). Under Proposition 14, which was passed in 2010, California adopted a nonpartisan blanket primary for most non-Presidential elections under which all candidates for a particular office, regardless of party, are placed on the same primary ballot. The top two finishers then advance to the general election regardless of party, so that general elections can pit two members of the same party against one another. Advocates of Proposition 14 argued that it would promote competition and reduce polarization by allowing independent voters to participate in primary elections, making it more likely that moderate candidates would emerge (prior to Proposition 14, independent voters ability to participate in primaries was limited). Even in dis- 
tricts dominated by one party, the top two primary can produce more moderate candidates as each candidate now angles to attract the median voter in the entire district rather than the median Democratic or Republican voter, as is the case when primaries are closed.

\section{The Impact of Redistricting on Competitiveness and Polarization}

The impact of redistricting on the competitiveness of congressional elections and on political polarization depends on how redistricting is conducted. Most importantly, it depends on whether redistricting is legislative or non-legislative in nature. Legislative redistricting is conducted by a state's legislature, which develops a redistricting plan that it must ultimately pass and which the governor typically must approve. Non- legislative redistricting occurs when a non-legislative body is vested with the authority to conduct redistricting. In many cases, however, non-legislative bodies are not fully vested with this authority and serve in an advisory or backup capacity. Non-legislative bodies can also have very different compositions, ranging from legislators or ex-legislators to judges to non-partisan staff to ordinary citizens. In what follows, I first discuss the impact of legislative redistricting on electoral competitiveness and political polarization and then consider the impact of non-legislative redistricting.

Legislative redistricting can be partisan or bipartisan in nature. Partisan redistricting occurs when a single party controls both the legislature and the governorship. Bipartisan redistricting occurs when control of the legislature and governorship is split across party lines. The impact of partisan and bipartisan legislative redistricting on competition and polarization are likely to be quite different.

Under a partisan redistricting plan, the usual goal is to maximize the number of seats controlled by the majority party. This requires redistricting in a manner that maximizes the efficiency with which the majority party's voters are distributed across district lines. Ordinarily this involves "packing" as many of the minority party's voters into as few districts as possible and "cracking" the rest across the remaining districts. The impact on competition and polarization depends on the exact mix of packing and cracking. If packing is dominant, the bulk of minority party voters are crammed into a few districts, creating lopsided races in many districts and a high degree of polarization within the congressional delegation. If cracking is dominant, competition will not necessarily suffer and polarization will not necessarily increase as minority party voters are distributed more evenly across a state's congressional districts. Cain (1985) shows that cracking minority party voters carefully can increase majority party seats without necessarily putting seats already held by the majority party at greater risk.

Bipartisan redistricting plans generally reduce competition and enhance polarization because the goal is incumbent protection. When state governance is split, no single party can dictate the terms of redistricting, so the status quo is likely to prevail unless no redistricting plan is agreed to, in which case redistricting may be conducted judicially or non-legislatively. Both possibilities pose a significant threat to incumbents, 
who may be displaced or even forced to run against one another. To avoid this outcome, redistricting is likely to redistribute voters in a manner that further entrenches incumbents and in this way undermines competition and enhances polarization. California's experience with bipartisan redistricting in the 2000 redistricting cycle provides a particularly good example of incumbent protection.

It is important to note that legislative redistricting is constrained by a number of factors. For example, all congressional districts must contain equal populations and any redistricting plan must be consistent with the Voting Rights Act of 1965. The importance of other criteria, such as compactness, contiguity, and respect for existing political subdivisions, vary depending on state law and legislative practice. Despite these constraints, legislatures often have considerable flexibility when designing redistricting plans.

Non-legislative redistricting is not as well defined as legislative redistricting, in part because it takes a wider variety of forms. Typically non-legislative redistricting involves the establishment of a redistricting commission. The commission can be either political or independent in nature. Political commissions have as members sitting legislators and/or other elected officials while independent commissions exclude elected officials and are typically designed to be nonpartisan. The scope of a redistricting commission's responsibilities may also vary, ranging from developing redistricting plans to serving in an advisory capacity. Non-legislative redistricting can also serve as a backstop should legislative redistricting fail to produce a plan. Plans developed by a redistricting commission may or may not be subject to approval by the legislature and/or the governor.

The impact of redistricting commissions on competitiveness and polarization hinges on three factors. First, is the redistricting commission truly independent of the legislature? Second, does the redistricting commission have full authority to redistrict or does it merely serve an advisory or backup role? Third, do the criteria under which the redistricting commission operates foster greater competitiveness and reduced polarization? In California's case, the first two questions can be answered in the affirmative as the $\mathrm{CRC}$ is both independent and fully vested with the authority to conduct redistricting. The third question, however, must be answered in the negative as the CRC is not legally directed to consider either competitiveness or polarization in its deliberations. This means that the impact of the CRC on competitiveness and polarization can only be determined empirically. In what follows, I first assess the impact of the CRC on competitiveness and then consider the impact on polarization.

\section{The CRC's Impact on Competitiveness}

To assess the impact of California's CRC on the competitiveness of congressional elections, consider first how victory margins for winning candidates changed after the introduction of the CRC. Table 1 presents data on victory margins from elections held during 2002-2004 and during 2012-2014. These two periods were selected for comparison because they represent the first two election cycles completed under each of California's two most recent redistricting plans. They show the immediate impact of redi- 
stricting under each redistricting plan and the subsequent impact once candidates have had time to adjust to the new competitive environment.

Even a cursory inspection of Table 1 indicates a significant increase in competition in the 2012-2014 period after the CRC plan was introduced relative to the 2002-2004 period. The mean and median victory margins dropped significantly for all races, for just those races including two opposing major party candidates, and for all other races. Most telling, 98 of the 106 congressional races held in 2002 or 2004 produced a victory margin of greater than 20 percent; in contrast, just 58 of 106 congressional races held in 2012 or 2014 produced a victory margin of greater than twenty percent. Similarly, only two congressional races held in 2002 or 2004 produced a victory margin of ten percent or less. Between 2012 and 2014, twenty two congressional races had a victory margin of

Table 1. Victory margins before and after the introduction of the CRC.

\begin{tabular}{|c|c|c|}
\hline & 2002-04 & 2012-14 \\
\hline \multicolumn{3}{|l|}{ All elections } \\
\hline Number of elections & 106 & 106 \\
\hline Mean victory margin & 40.4 & 28.9 \\
\hline Median victory margin & 37.0 & 22.0 \\
\hline Number of victory margins, $0 \%$ to $5 \%$ & 0 & 11 \\
\hline Number of victory margins, $5 \%$ to $10 \%$ & 2 & 11 \\
\hline Number of victory margins, $10 \%$ to $20 \%$ & 6 & 26 \\
\hline Number of victory margins greater than 20 percent & 98 & 58 \\
\hline \multicolumn{3}{|l|}{ Elections with opposing major party candidates } \\
\hline Number of elections & 99 & 83 \\
\hline Mean victory margin & 37.6 & 28.5 \\
\hline Median victory margin & 37.0 & 22.0 \\
\hline Number of victory margins, $0 \%$ to $5 \%$ & 0 & 9 \\
\hline Number of victory margins, $5 \%$ to $10 \%$ & 2 & 8 \\
\hline Number of victory margins, $10 \%$ to $20 \%$ & 6 & 20 \\
\hline Number of victory margins greater than 20 percent & 91 & 46 \\
\hline \multicolumn{3}{|l|}{ All other elections } \\
\hline Number of elections & 7 & 23 \\
\hline Mean victory margin & 80.9 & 30.6 \\
\hline Median victory margin & 78.0 & 22.0 \\
\hline Number of victory margins, $0 \%$ to $5 \%$ & 0 & 2 \\
\hline Number of victory margins, $5 \%$ to $10 \%$ & 0 & 3 \\
\hline Number of victory margins, $10 \%$ to $20 \%$ & 0 & 6 \\
\hline Number of victory margins greater than 20 percent & 7 & 12 \\
\hline
\end{tabular}

Source: Author's calculations based on data from the Almanac of American Politics. 
Table 2. Incumbent reelection rates for California House members.

\begin{tabular}{ccccc}
\hline $\begin{array}{c}\text { Election } \\
\text { year }\end{array}$ & $\begin{array}{c}\text { Total number } \\
\text { of incumbents } \\
\text { reelected }\end{array}$ & $\begin{array}{c}\text { Number of incumbents } \\
\text { defeated in primary or } \\
\text { general elections }\end{array}$ & $\begin{array}{c}\text { Number of incumbents } \\
\text { retiring, resigning, or } \\
\text { deceased }\end{array}$ & $\begin{array}{c}\text { Number of incumbents } \\
\text { seeking or accepting } \\
\text { another office }\end{array}$ \\
\hline $2002-04$ & 101 & 1 & 3 & 0 \\
$2012-14$ & 86 & 7 & 12 & 1 \\
\hline
\end{tabular}

Source: Author's calculations based on data from the Almanac of American Politics.

ten percent or less. Clearly competition increased significantly in the period after the introduction of the CRC plan relative to the period after the introduction of the prior redistricting plan.

Did the increase in competition translate into greater turnover within California's congressional delegation? Table 2 provides data on incumbent turnover during the 2002-2004 period and the 2012-2014 period. Overall, there was clearly greater turnover in the period after the CRC was introduced. Four incumbents left office or were defeated in the 2002-2004 period while 20 incumbents left office or were defeated in the 2012-2014 period. In the earlier period, only a single incumbent was defeated in a primary or general election; in contrast, seven incumbents were defeated in primary or general elections in the later period. Furthermore, more than four times the number of incumbents left office in the 2012-2014 period than in the 2002-2004 period. While many if not most of these retirements and resignations were not motivated by redistricting, some almost certainly were, including that of David Drier, Elton Gallegly and Gary Miller ${ }^{4}$. Clearly there was greater incumbent turnover in the period after the CRC plan was implemented than in the period after the prior redistricting plan was implemented.

Electoral competition also depends on the quality of incumbent challengers. To identify challenger quality, I rely on two factors. The first factor is whether a challenger has previously been elected to public office ${ }^{5}$. Challengers gain valuable experience when they successfully run for public office at any level and this experience enables them to run more effective campaigns in the future (Jacobson \& Kernell, 1981). The second factor is the ability of challengers to raise funds. Greater challenger spending has been shown to significantly enhance a challenger's likelihood of victory (Jacobson, 1990). I consider a challenger to be well financed if they are able to raise at least 25 percent of the funds raised by the incumbent ${ }^{6}$. I use the 25 percent cutoff because all 8 challengers who defeated incumbents in my sample raised at least this share.

I define three levels of challenger quality. A low-quality challenger has neither held

${ }^{4}$ http://thecaucus.blogs.nytimes.com/2012/02/29/dreier-opts-out-of-re-election-bid/?_php=true\&_type=blogs \&_r=0,http://thecaucus.blogs.nytimes.com/2012/01/10/with-house-redistricting-looming-2-california-republi cans-retire/

${ }^{5} \mathrm{~A}$ number of sources were used to determine whether challengers had previously held public office, including The Almanac for American Politics, PoliticalGraveyard.com, ballotpedia.org, votesmart.org and the League of Women Voters of California Education Fund.

${ }^{6}$ Campaign contributions were taken from the The Almanac for American Politics (Barone, 2002, 2004, 2012, 2014) for the 2002, 2004 and 2012, 2014 elections and from ballotpedia.org for the 2012 elections. 
public office previously nor raised 25 percent of the funds raised by the incumbent. A quality challenger has either held public office before or has raised at least 25 percent of the funds raised by the incumbent. A high-quality challenger has both held public office before and raised at least 25 percent of the funds raised by the incumbent.

Table 3 displays the distribution of challenger quality across the 2002, 2004, 2012 and 2014 California congressional elections. Note first that the percentage of low-quality challengers in 2002 and 2004 is substantially greater than in 2012 and 2014. Conversely, the percentage of high quality challengers in 2002 and 2004 is substantially less than in 2012 and 2014. The percentage of quality challengers is roughly equivalent across the four elections. Again, the evidence indicates a more competitive electoral environment in the post-CRC period.

While the evidence presented in tables 1 through 3 appears compelling, it is important to note that Proposition 14 also went into effect with the 2012 elections. The introduction of blanket primaries in 2012 makes it difficult to determine the degree to which lower victory margins, greater incumbent turnover and higher challenger quality are the product of redistricting reform. For example, victory margins might decline in districts that are highly partisan because the blanket primary leads to two candidates from the dominant party facing off in the general election, rather than one candidate from the dominant party and one from the fringe party.

To address this problem, I now consider the effect of redistricting on voter registration patterns. Voter registration patterns are not impacted by the introduction of blanket primaries and thus any effect that shifts in these patterns might have on electoral competition can be linked directly to redistricting reforms. To assess the impact of redistricting on voter registration patterns, I use kernel density estimation to approximate the probability density function for Democratic registration as a percentage of major party registration across California's 53 congressional districts ${ }^{7}$. Figure 1 shows the combined results for the 2002-2004 and 2012-2014 congressional elections. The most striking aspect of Figure 1 is the bimodal distribution of Democratic registration associated with the 2002-2004 elections, which is exactly what would be expected under the bipartisan gerrymander enacted in 2001. Notice that the bimodality apparent in the distribution for the 2002-2004 elections is almost entirely absent in the distribution for the 2012-2014 elections. As a consequence, one might anticipate that competition would be greater in the 2012-2014 elections. This comparison is somewhat misleading

Table 3. Quality of incumbent challengers.

\begin{tabular}{cccccc}
\hline $\begin{array}{c}\text { Election } \\
\text { year }\end{array}$ & $\begin{array}{c}\text { Total number } \\
\text { of incumbents }\end{array}$ & $\begin{array}{c}\text { Total number of } \\
\text { incumbent } \\
\text { challengers }\end{array}$ & $\begin{array}{c}\text { Percentage of } \\
\text { low-quality } \\
\text { challengers }\end{array}$ & $\begin{array}{c}\text { Percentage of } \\
\text { quality } \\
\text { challengers }\end{array}$ & $\begin{array}{c}\text { Percentage of } \\
\text { high-quality } \\
\text { challengers }\end{array}$ \\
\hline $2002-04$ & 101 & 99 & 81.8 & 17.2 & 1.0 \\
$2012-14$ & 93 & 91 & 67.0 & 15.4 & 17.6 \\
\hline
\end{tabular}

Source: Author's calculations. See footnotes 4 and 5.

${ }^{7}$ Registration data are from the website of the California Secretary of State (http://www.sos.ca.gov/) and from http://statewidedatabase.org/report_of_registration.html. 


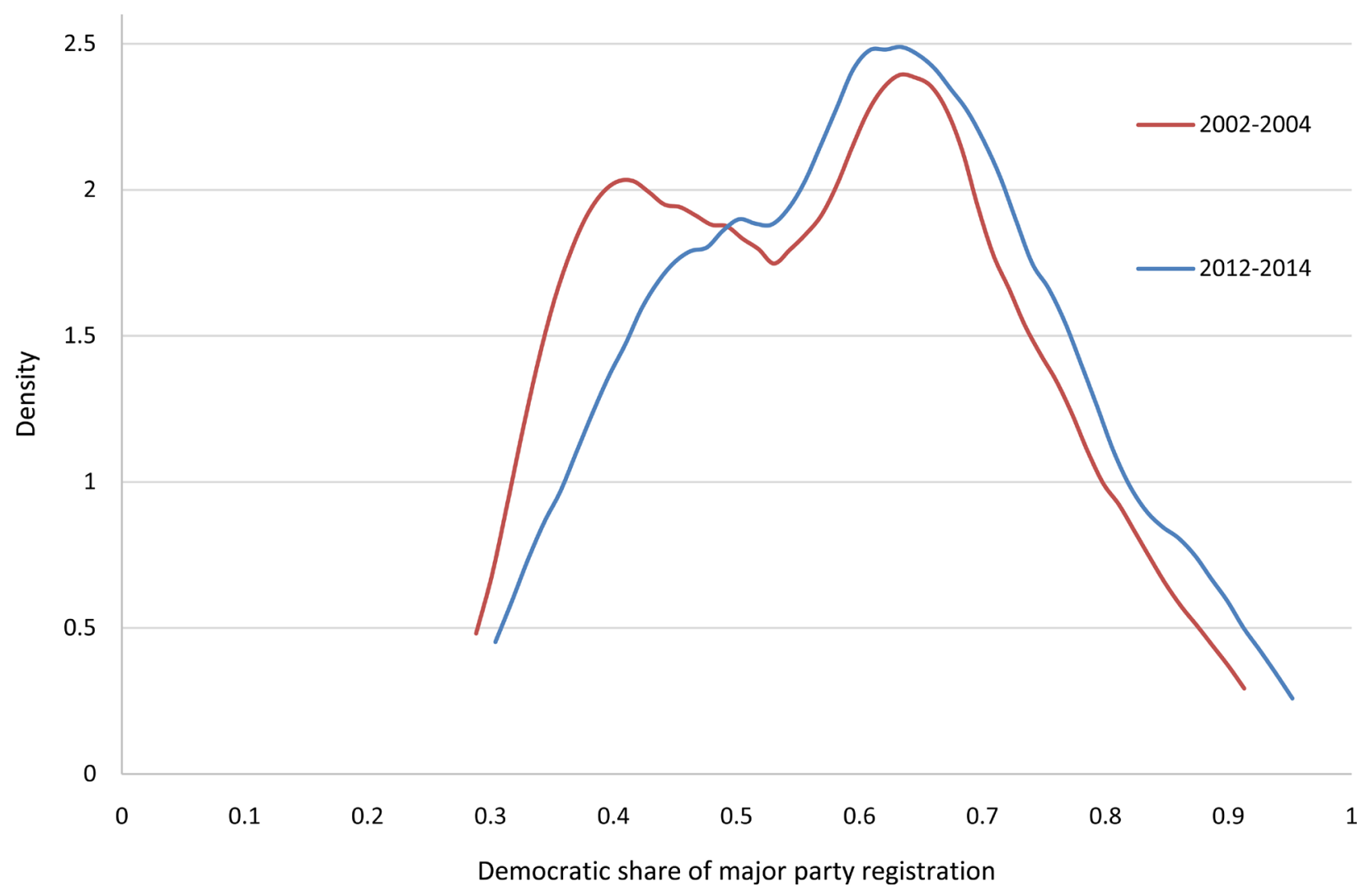

Figure 1. Distribution of Democratic share of major party registration.

however, as it ignores a significant increase in the Democratic Party's share of major party registration in California during this period. This share rose from 55.6 percent in the 2002-2004 elections to 60.2 percent in 2012-2014 elections, producing registration patterns that more clearly favored Democratic candidates. Absent this increase, the distribution for the 2012-2014 elections would shift left, almost certainly enhancing the competitive impact of redistricting reform.

To more precisely estimate how electoral competition might be affected by changes in voter registration patterns brought about by redistricting, I now regress the Democratic share of the major party vote on the Democratic share of major party registration. As control variables, I use the Democratic share of major-party campaign contributions and dummy variables for Democratic and Republican incumbents. The model is estimated using data from the 2002, 2004, 2012 and 2014 California congressional elections.

Table 4 presents the regression results. Not surprisingly, the coefficients on both the Democratic share of major-party registration and the Democratic share of major-party campaign contributions are positive and statistically significant at very high levels, indicating that increases in either variable positively affect the Democratic share of the major-party vote. Somewhat surprisingly, incumbency doesn't seem to impact the Democratic share of the major-party vote, at least after campaign contributions are controlled for. 
Table 4. Estimated model for Democratic share of major party vote simulation (standard errors in parentheses).

\begin{tabular}{cc}
\hline Democratic share of major party registration & $0.743^{*}$ \\
Democratic share of major party campaign contributions & $(0.096)$ \\
Dummy variable for Democratic incumbent & $0.349^{*}$ \\
Dummy variable for Republican incumbent & $(0.046)$ \\
Observations & -0.007 \\
R & $(0.028)$ \\
Root Mean Squared Error & 0.046 \\
Rer & $0.031)$ \\
\hline
\end{tabular}

*Statistically significant at the one percent level.

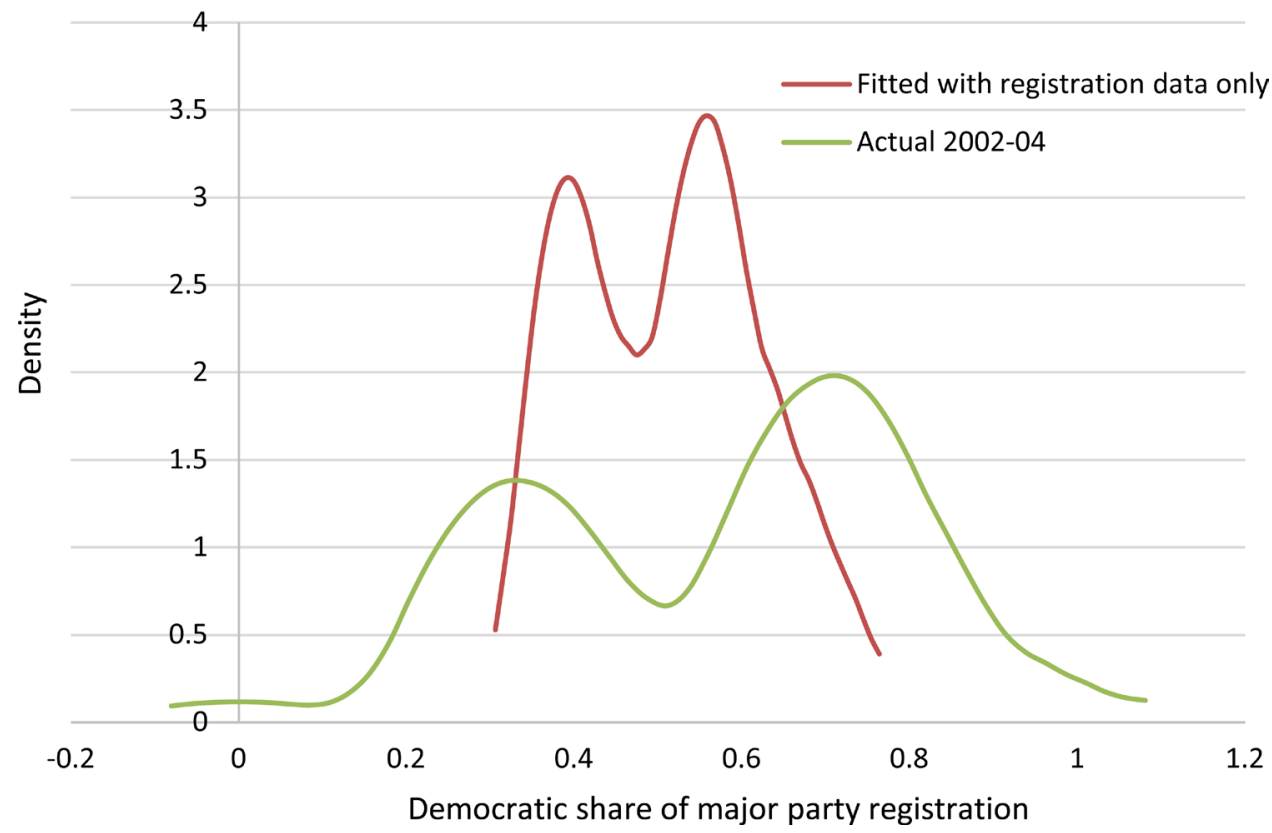

Figure 2. Registration and the Democratic share of the major party vote, 2002-2004.

The model in Table 4 is now used to simulate the effect of the Democratic share of major-party registration on the Democratic share of the major-party vote. To determine this effect, I first set the Democratic share of major-party campaign contributions equal to 0.5 for all observations and then set the dummy variables equal to zero, again for all observations. The effect of the Democratic share of major-party registration on the Democratic share of the major-party vote is then simulated.

Figure 2 and Figure 3 show the results of this simulation exercise. Both figures provide two kernel densities: the first kernel density reflects the distribution of fitted values from the simulation exercise just described; the second kernel density reflects the distribution of the actual values for the Democratic share of the major-party vote. Figure 2 


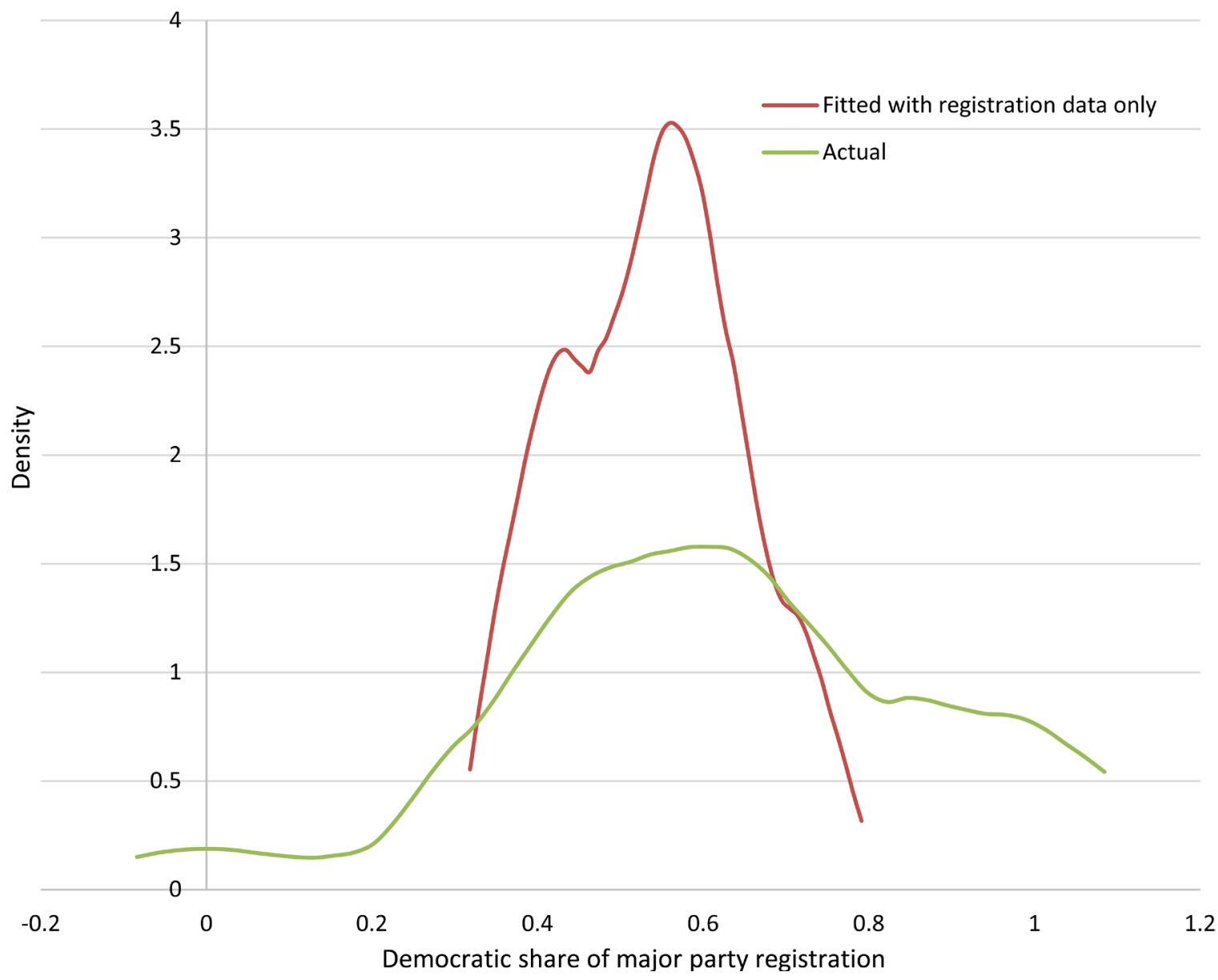

Figure 3. Registration and the Democratic share of the major party vote, 2012-2014.

uses data from the 2002 and 2004 elections while Figure 3 uses data from the 2012 and 2014 elections.

Two observations are relevant for both figures. First, the fitted values produced using only registration data are clearly correlated with the actual distribution of the Democratic share of the major-party vote. The bimodal distribution predicted by the registration data for the 2002 and 2004 elections is clearly evident in the actual distribution of the Democratic share of the major-party vote. Similarly, the unimodal distribution predicted by the registration data for the 2012 and 2014 elections is also clearly evident in the actual distribution of the Democratic share of the major-party vote. Thus the change in registration patterns brought about by the CRC clearly influenced election outcomes and did so in a manner that enhanced competition.

Second, while registration patterns clearly influence electoral outcomes, other factors do so as well. In both figures, the distribution of fitted values has a much lower standard deviation than the distribution of actual values, indicating the presence of other factors that serve to reduce competitiveness. Exactly what these other factors might be (incumbency, campaign contributions, etc.) is not clear, but what is clear is that redistricting reform by itself cannot be expected to fully restore competitive balance. 
In sum, all the measures of competitiveness considered in this section indicate that the redistricting plan put forward by the CDC bolstered electoral competition. The exact size of the effect remains unclear, in part because Proposition 14 was implemented simultaneously, but even if attention is limited to just voter registration patterns (the factor most clearly associated with redistricting) there is still evidence of a pro- competitive effect.

\section{Political Polarization}

Political polarization is a well-documented phenomenon in the U.S. Congress (McCarty, Poole, \& Rosenthal 2006; Nivola \& Brady, 2006), so it should not be surprising to observe it within California's House delegation. Figure 4 presents mean "common space" DW-Nominate scores for all members of California's House delegation, broken down both by party and by Congressional session ${ }^{8}$. Before going any further, it is important to note that common space DW-nominate scores are time invariant for each individual legislator. Poole (2007) provides both a theoretical argument for this time invariance as well as empirical support for it. For the purpose of this paper, time invariance implies that increasing polarization can only be the result of an electoral

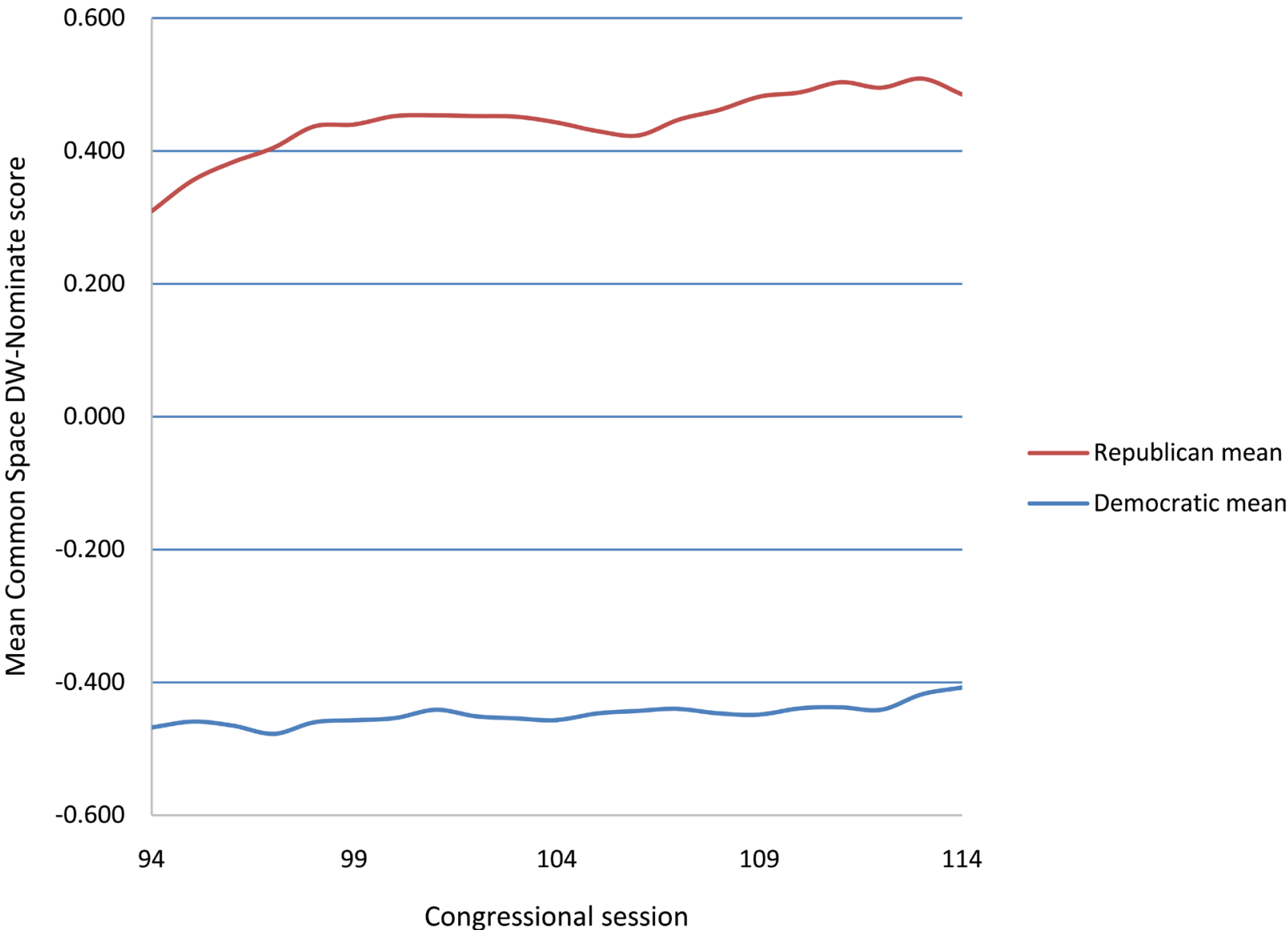

Figure 4. Polarization of California's House Delegation.

$$
{ }^{8} \text { Poole, } 1998 .
$$


process in which less ideologically-extreme legislators are replaced by more ideologically-extreme legislators. Any effects on polarization resulting from shifts in the preferences of individual legislators are ruled out.

Figure 4 shows a growing ideological divide between California's Democratic and Republican House delegations during the period covering the 94th through 114th Congressional sessions. What is most intriguing about this divergence is that it is entirely the result of increased polarization on the part of California's House Republicans. California's House Democrats have, if anything, moderated their ideological position slightly over the last 40 years. This pattern is at odds with the standard argument for polarization based on incumbent protection. According to this argument, polarization should occur among both Democrats and Republicans as districts become increasingly blue and increasingly red. The fact that polarization is so one-sided suggests that redistricting based on incumbent protection is not responsible for the polarization of California's congressional delegation.

Redistricting may still contribute to polarization, however, as long as it can be shown that increased polarization on the part of Republicans reflects shifts in voter registration patterns engendered by redistricting. While it is difficult to isolate changes in voter registration patterns resulting exclusively from redistricting, overall voter registration patterns (as depicted in Figure 5) are consistent with the argument that increasing polarization on the part of Republicans is at least partly attributable to redistricting. Thus the steady increase in the mean common space DW-Nominate score for California's House Republicans seen in Figure 4 is matched by a steady decline in the Democratic share of major party registration in districts held by Republicans, as seen in Figure 5. Similarly, the modest decline in polarization on the part of California's House Democrats is matched by a modest but irregular decline in the Democratic share of major party registration in districts held by Democrats.

A preliminary gauge of the CRC's impact on polarization is provided in Table 5. The

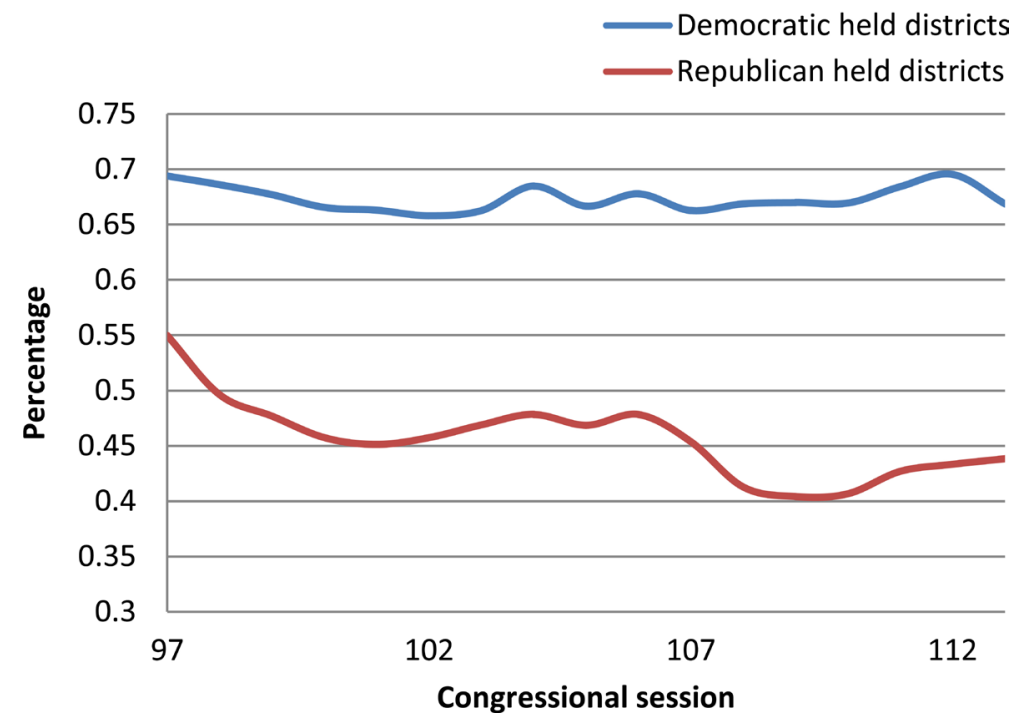

Figure 5. Democratic share of major party registration by congressional session. 
Table 5. New and departing House members since the introduction of the California Redistricting Commission.

\begin{tabular}{|c|c|c|c|}
\hline $\begin{array}{l}\text { New members since the } \\
\text { introduction of the California } \\
\text { Redistricting Commission }\end{array}$ & $\begin{array}{l}\text { Common Space } \\
\text { DW-Nominate }\end{array}$ & $\begin{array}{l}\text { Departing members since the } \\
\text { introduction of the California } \\
\text { Redistricting Commission }\end{array}$ & $\begin{array}{l}\text { Common Space } \\
\text { DW-Nominate }\end{array}$ \\
\hline DeSaulnier & -0.518 & Filner & -0.651 \\
\hline Takano & -0.497 & Stark & -0.637 \\
\hline Lowenthal & -0.465 & Woolsey & -0.564 \\
\hline Negrete McLeod $^{2}$ & -0.453 & Miller, George & -0.557 \\
\hline Huffman & -0.447 & Waxman & -0.477 \\
\hline Hahn & -0.417 & Negrete McLeod & -0.453 \\
\hline Vargas & -0.393 & Berman & -0.406 \\
\hline Cardenas & -0.386 & Baca & -0.347 \\
\hline Swalwell & -0.381 & Richardson & -0.342 \\
\hline Lieu & -0.360 & Harman & -0.263 \\
\hline Torres & -0.358 & Cardoza & -0.260 \\
\hline Aguilar & -0.279 & Lewis & 0.350 \\
\hline Brownley & -0.275 & Bono-Mack & 0.358 \\
\hline Ruiz & -0.224 & Bilbray & 0.399 \\
\hline Bera & -0.215 & McKeon & 0.401 \\
\hline Peters & -0.174 & Gallegly & 0.405 \\
\hline Valadao & 0.267 & Miller, Gary & 0.480 \\
\hline Walters & 0.387 & Dreier & 0.480 \\
\hline Knight & 0.411 & Lungren & 0.501 \\
\hline Cook & 0.420 & Herger & 0.553 \\
\hline LaMalfa & 0.582 & Campbell & 0.759 \\
\hline Standard deviation & 0.355 & & 0.488 \\
\hline Maximum & 0.582 & & 0.759 \\
\hline Minimum & -0.518 & & -0.651 \\
\hline
\end{tabular}

${ }^{1}$ http://voteview.uga.edu/ftp/junkord/HANDSL01114A20_STAND_ALONE_23.DAT

${ }^{2}$ Negrete McLeod was elected to the 113th Congress but did not run for reelection to the 114th Congress.

table provides Common Space DW-Nominate scores for all representatives who have either been first elected since the introduction of the CRC or have left office since then. The table clearly shows that new members as a group are more moderate than departing members. Thus the range of Common Space DW-Nominate scores for new members is lower than that of departing members, as is the standard deviation of the distribution of Common Space DW-Nominate scores. The number of moderates (Common Space DW-Nominate scores between -0.3 and 0.3 ) also grew substantially, increasing from two to six. 
This preliminary analysis, while suggestive, is flawed for two reasons. First, while it shows a reduction in polarization since the introduction of the CRC, this reduction cannot be attributed entirely or even in part to redistricting reform because Proposition 14 went into effect at the same time as redistricting reform. Proposition 14, which created blanket Congressional primaries, can be expected to have a moderating effect on polarization because Congressional candidates must now appeal to the median blanket primary voter rather than the median Democratic or Republican primary voter, as was the case with closed primaries (Amoros et al., 2016). Second, the full effect of redistricting reform on polarization will take many years to play out as incumbent House members elected prior to redistricting reform are likely to remain more polarized than those who have been elected since. If, as Poole (2007) argues, legislators do indeed "die in their ideological boots", then the full effect of redistricting reform on polarization will not be felt until California's Congressional delegation has completely turned over.

To get a better measure of how the CRC's plan is likely to impact polarization, I estimate a simple regression model and use it simulate the impact of redistricting on polarization. The dependent variable is a House member's Common Space DW-Nominate score, which ranges from -1 (most liberal) to 1 (most conservative) and is time invariant. I use DW-Nominate scores from the 108th, 109th, 113th and 114th sessions of Congress, which correspond to the two sessions of Congress following the two most recent redistricting cycles in 2000 and 2010. The independent variable is the Democratic share of major party registration in the preceding election year. The Democratic share of major party registration reflects the impact of redistricting and other factors that are determined independently of Proposition 14. I also include the square of this share as there is evidence of curvature in the relationship between DW-Nominate scores and the Democratic share of major party registration.

The estimated model is presented in Table 6. As is evident from the table, the simple regression model fits the data quite well. The coefficient estimates are all statistically significant at the one percent level and the coefficient signs indicate that an increase in the Democratic share of major party registration reduces a legislator's DW-Nominate score but at a diminishing rate. The model explains most of the variation in legislator

Table 6. Estimated model for polarization simulation (standard errors in parentheses).

$\begin{array}{cc}\text { Constant } & 3.72^{\star} \\ & (0.19) \\ \text { Democratic share of major party registration } & -10.78^{\star} \\ \text { Democratic share of major party registration squared } & (0.64) \\ \text { Observations } & 6.79^{*} \\ \mathrm{R}^{2} & (0.53) \\ \text { Root Mean Squared Error } & 214 \\ \end{array}$

*Statistically significant at the one percent level. 
ideology across congressional districts, suggesting that voters within individual districts elect candidates whose ideological positions reflect their own. If this is indeed the case, redistricting has the potential to reduce polarization if it can produce districts whose electorates are less politically extreme.

The regression model is now used to simulate the effect of the CRC's redistricting plan on political polarization. To conduct the simulations, the fitted values from the regression are obtained and the distribution of these values is then plotted using kernel density estimation. The results for California's House delegation are presented in Figure 6. In the figure, results for the 108th and 109th Congressional sessions are combined, as are results for the 113th and 114th sessions. The figure shows that the change in registration patterns resulting at least in part from redistricting does appear to have reduced polarization. In particular, there are more moderate members in the 2013th and 2014th sessions than in the earlier sessions, which is consistent with what was actually observed (see Table 5). The figure also shows a significant ideological shift to the left, which is most likely the result of the rising Democratic share of major party registration in California over the last decade.

In sum, the turnover in California's House delegation in the aftermath of the 2010 redistricting reform produced a more moderate and less polarized delegation. This moderation is linked at least in part to shifts in voter registration patterns engendered

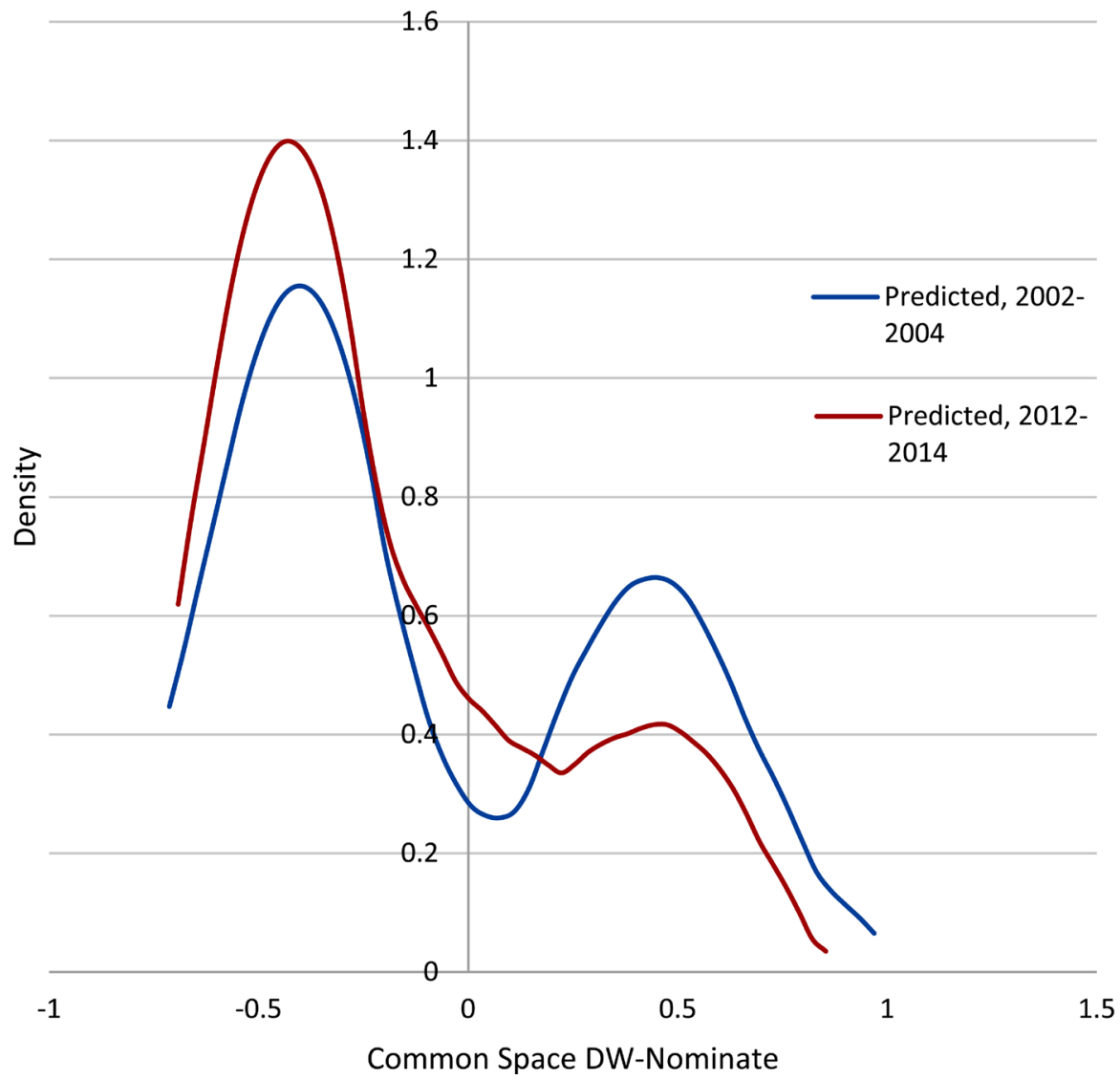

Figure 6. Polarization simulation results. 
by redistricting. Whether Proposition 14 also contributed to this moderation is not clear from the evidence presented here.

\section{Conclusion}

The results of this paper indicate that independent redistricting commissions operating under traditional redistricting criteria can be expected to increase electoral competition and reduce political polarization. The exact extent of these effects is difficult to gauge, however, as the CRC has been in effect for only two elections. It is possible that the effects observed in this paper will strengthen over time as more incumbents retire or are defeated. It is also possible, however, that the observed effect is simply a one-time adjustment that will largely disappear once a new group of incumbents become entrenched. Only time will tell, but it does seem reasonable to infer that a modest increase in competition and a modest reduction in polarization are likely to endure.

If this is the case, then redistricting reform is a not a silver bullet that will singlehandedly solve the problems of reduced competition and increased polarization at the congressional level. Perhaps it is unfair to expect redistricting reform to achieve so much, however. Redistricting reforms like those undertaken by California are designed with many goals in mind, including not only greater accountability but also increased transparency and greater citizen participation. From this perspective, modest improvements in accountability must be combined with other indicators before any real assessment of redistricting reform can be made.

While it would be interesting to determine the exact extent to which redistricting reform can increase political accountability if that were its only focus, such a determination would be a purely hypothetical exercise. Redistricting requirements related to population size, minority representation, compactness, contiguity and so on limit what can be achieved through redistricting reform with respect to competitiveness or polarization. And few would argue that it should be otherwise. Drawing district lines is a complex process that involves juggling inherently contradictory criteria. The crucial question is who is the best situated to strike the appropriate balance. More research is clearly necessary before this question can be answered definitively.

\section{References}

Abramowitz, A. I., Brad, A., \& Matthew, G. (2006). Incumbency, Redistricting, and the Decline of Competition in US House Elections. The Journal of Politics, 68, 75-88. http://dx.doi.org/10.1111/j.1468-2508.2006.00371.x

Amoros, P. M., Socorro, P., \& Ricardo, M. (2016). Closed Primaries versus Top-Two Primaries. Public Choice, 167, 21-35. http://dx.doi.org/10.1007/s11127-016-0328-5

Barone, M. (2002/2004/2012/2014). The Almanac of American Politics. Washington DC: National Journal Group.

Cain, B. E. (1985). Assessing the Partican Effects of Redistricting. The American Political Science Review, 79, 320-333. http://dx.doi.org/10.2307/1956652

Cain, B. E. (2012). Redistricting Commissions: A Better Political Buffer? Yale Law Journal, 121, 1808-1844. 
Carson, J. L., Crespin, M. H., \& Williamson, R. D. (2014). Reevaluating the Effects of Redistricting on Electoral Competition, 1972-2012. State Politics and Policy Quarterly, 14, 162-174. http://dx.doi.org/10.1177/1532440013520245

Carson, J. L., Crespin, M. H., Finocchiaro, C. J., \& Rohde, D. W. (2007). Redistricting and Party Polarization in the US House of Representatives. American Politics Research, 35, 878-904. http://dx.doi.org/10.1177/1532673X07304263

Chen, J., \& Rodden, J. (2013). Unintentional Gerrymandering: Political Geography and Electoral Bias in Legislatures. Quarterly Journal of Political Science, 8, 239-269. http://dx.doi.org/10.1561/100.00012033

Grainger, C. A. (2010). Who Draws the Lines in California? Journal of Law and Economics, 53, 545-567. http://dx.doi.org/10.1086/605724

Jacobson, G. C. (1990). The Effects of Campaign Spending in House Elections: New Evidence for Old Arguments. American Journal of Political Science, 34, 334-362. http://dx.doi.org/10.2307/2111450

Jacobson, G. C., \& Kernell, S. (1981). Strategy and Choice in Congressional Elections. New Haven, CT: Yale University Press.

Kogan, V., \& McGhee, E. (2012). Redistricting California: An Evaluation of the Citizens Commission Final Plans. The California Journal of Politics and Policy, 4, 1-32. http://dx.doi.org/10.5070/P23K5Q

Kogan, V., \& McGhee, E. (2013). Redistricting: Did Radical Reform Produce Different Results? In E. Rarick (Ed.), Governing California: Politics, Government, and Public Policy in the Golden State Berkley (pp. 151-174). Berkeley, CA: Berkley Public Policy Press.

Kogan, V., \& Kousser, T. (2011). Great Expectations and the California Citizens Redistricting Commission. In G. Moncrief (Ed.), Reapportionment and Redistricting in the West (pp. 219-245). Lanham, MD: Lexington Books.

Kousser, T., Phillips, J., \& Shor, B. (2014). Reform and Representation: A New Method Applied to Recent Electoral Changes. Working Paper.

Mann, T. E. (2006). Polarizing the House of Representatives: How Much Does Gerrymandering Matter? In P. S. Nivola, \& D. W. Brady (Eds.), Red and Blue Nation? Characteristics and Causes of America's Polarized Politics (pp. 263-283). Washington DC: Brookings Institution Press.

Masket, S. (2013). Polarization Interrupted? California's Experiment with the Top-Two Primary. In E. Rarick (Ed.), Governing California: Politics, Government, and Public Policy in the Golden State Berkley (pp. 175-190). Berkeley, CA: Berkley Public Policy Press.

Masket, S. E., Winburn, J., \& Wright, G. C. (2012). The Gerrymanderers Are Coming! Legislative Redistricting Won't Affect Competition or Polarization Much, No Matter Who Does It. Political Science and Politics, 45, 39-43. http://dx.doi.org/10.1017/S1049096511001703

McCarty, N. M., Poole, K. T., \& Rosenthal, H. (2006). Polarized America: The Dance of Ideology and Unequal Riches. Cambridge: MIT Press.

McDonald, M. P. (2006). Drawing the Lines on District Competition. Political Science and Politics, 39, 91-94. http://dx.doi.org/10.1017/S1049096506060161

Miller, P., \& Grofman, B. (2013). Redistricting Commissions in the Western United States. UC Irvine Law Review, 3, 637-668.

Nivola, P. S., \& Brady, D. W. (2006). Red and Blue Nation? Characteristics and Causes of America's Polarized Politics. Washington DC: Brookings Institution Press.

Passantino, G. (2008). Redistricting in California: Competitive Elections and the Effects of Proposition 11 (Policy Brief 72). Los Angeles, CA: Reason Foundation. 
Poole, K. T. (1998). Recovering a Basic Space from a Set of Issue Scales. American Journal of Political Science, 42, 954-993. http://dx.doi.org/10.2307/2991737

Poole, K. T. (2007). Changing Minds? Not in Congress! Public Choice, 131, 435-451. http://dx.doi.org/10.1007/s11127-006-9124-y

Theriault, S. M. (2008). Party Polarization in Congress. New York: Cambridge University Press. http://dx.doi.org/10.1017/CBO9780511790652

Winburn, J. (2011). Does It Matter If Legislatures or Commissions Draw the Lines? In G. Moncrief (Ed.), Reapportionment and Redistricting in the West (pp. 137-160). Lanham, MD: Lexington Books.

Submit or recommend next manuscript to SCIRP and we will provide best service for you:

Accepting pre-submission inquiries through Email, Facebook, LinkedIn, Twitter, etc. A wide selection of journals (inclusive of 9 subjects, more than 200 journals)

Providing 24-hour high-quality service

User-friendly online submission system

Fair and swift peer-review system

Efficient typesetting and proofreading procedure

Display of the result of downloads and visits, as well as the number of cited articles Maximum dissemination of your research work

Submit your manuscript at: http://papersubmission.scirp.org/

Or contact ojps@scirp.org 